\title{
Estimation of Internal Maximum Thermal Stress of Tunnel Side Wall Lining Concrete During Construction Period
}

\author{
Y H DUAN $^{\mathrm{a}, \mathrm{b}}, \mathrm{H} \mathrm{M} \mathrm{YANG}^{\mathrm{a}, 1}, \mathrm{~J} \mathrm{P} \mathrm{YUAN}^{\mathrm{a}}, \mathrm{L} \mathrm{SU}^{\mathrm{c}}$ and W T LI ${ }^{\mathrm{c}}$ \\ ${ }^{a}$ School of Intelligent Construction, Wuchang University of Technology, Wuhan, China \\ ${ }^{\mathrm{b}}$ School of Water Resources and Hydropower Engineering, Wuhan University, Wuhan, \\ China \\ ${ }^{\mathrm{c}}$ China Three Gorges Construction Management Co., Ltd., Chengdu, China
}

\begin{abstract}
Thermal cracks in lining concrete of large section hydraulic tunnel usually occur in side walls during construction, and most of them are harmful penetrating cracks. In order to meet the needs of real-time rapid control for engineering design in construction period, nine influencing factors of maximum tensile of side wall lining concrete $\sigma_{\max }$ during construction period are determined on the basis of comprehensive analysis of temperature stress effects and finite element simulations, and their influencing regularities are analyzed. Then the estimation formula of $\sigma_{\max }$ and real-time control method of thermal crack are put forward. Through the application of real-time temperature control and crack prevention control of lining concrete in flood discharge tunnel, the estimation formula of $\sigma_{\max }$ and the real-time thermal crack control method are proved to be correct and applicable.
\end{abstract}

Keywords. Hydraulic tunnel, lining concrete, thermal crack, temperature control and crack prevention, medium heat cement

\section{Introduction}

The flood discharge tunnel of large hydropower station has large section, high flow rate, high concrete strength and large hydration heat, and the thin-wall lining is strongly restrained by surrounding rock and support structure. During construction period, temperature cracks occur when tensile stress exceeds tensile strength under the action of large temperature difference and rapid temperature drop, and most of them are penetrating dangerous cracks [1-4]. For the section structure of city gate type, the risk of temperature cracks in side wall during construction period is significantly higher than that of bottom plate. For example, as for no pressure section in the four flood discharge tunnels in Xiluodu, only 2 silos have cracks in the bottom slab and cracks occurred in 102 silos of side wall [1]. Temperature cracks in the unconfined section of Xiaolangdi hydraulic tunnel mostly occur in the high-strength lined side wall [5].

In order to control the temperature crack of the side wall lining concrete of the flood discharge tunnel, Duan et al. improved creep model for eliminating negative

\footnotetext{
${ }^{1}$ H M Yang, School of Intelligent Construction, Wuchang University of Technology, Wuhan, China; E-mail: 274550641@qq.com.
} 
creep [6-7], effectively improving the accuracy of temperature stress calculation for early creep. The temperature and temperature stress of lining concrete of the underground water conveyance tunnel of the permanent lock of the Three Gorges Project during construction period are monitored on site, simulated by FEM, calculated by the theory of embedded plates and the equivalent creep method, and the scheme of temperature crack control is put forward [8-14]. Liu et al. adopted finite element method to simulate temperature and temperature stress of Xiaolangdi and Xiluodu, and put forward temperature control standard for lining concrete of flood discharge tunnel [15-16]. Kumar and Singh discussed the influence of temperature variation of tunnel lining concrete on cracks [17]. Takayama et al. proposed a method to control the cracks of Shinkansen tunnel by model test of lining concrete and influence of factors observed on site [18].

As the calculation of finite element method, difference method, embedded plate theory and equivalent creep method are complicated, and a large number of concrete performance tests are required to obtain corresponding calculation parameters. It can not predict in a timely manner and take effective measures in some small and mediumsized projects without test parameters or changes in construction, which often lead to excessive temperature and temperature cracks. Therefore, it is necessary to have a simple and applicable temperature tensile stress estimation formula with high accuracy, which is used to quickly adjust the temperature control measures in the construction process, but also for small and medium-sized engineering design and construction reference application.

\section{Analysis of Factors Affecting Temperature Stress during Lining Concrete Construction Period}

There are many influencing factors of temperature stress of lining concrete during construction period, including lining structure, concrete performance, environmental conditions, construction temperature control measures, concrete maintenance and construction technology, etc. Because the purpose is to put forward the formula for calculating maximum temperature tensile stress $\left(\sigma_{\max }\right)$, of lining concrete during construction period, only the elements with greater influence are analyzed.

In terms of structure, section type and slit length $(\mathrm{L})$, circumferential length $\left(\mathrm{H}_{0}\right)$ and lining thickness $(\mathrm{H})$ are all influencing factors. For the side wall of the gate tunnel type, the ring length $\mathrm{H}_{0}$ is the height of the side wall, the separate casting of the side crown arch is the height of the straight wall of the casting block, and the overall casting of the side crown arch is the straight wall $+1 / 2$ arc length of the top arch. Internal reinforcing bars, Influence of over-jointed reinforcing bars, anchors, etc. are neglected .

In terms of concrete materials, the concrete elastic modulus is used in the stress calculation, as reflected by the concrete strength grade $(\mathrm{C})$ in the stress estimation.

Environmental factors include the surrounding rock and temperatures in the tunnel.The deformation modulus (E) is used to reflect the constrained properties of surrounding rock. The temperature in the tunnel is expressed by the temperature during concrete pouring period $\left(\mathrm{T}_{\mathrm{a}}\right)$ and the minimum temperature in the tunnel $\left(\mathrm{T}_{\min }\right)$. In winter, the tunnel entrance should be closed to maintain insulation, when $T_{a}$ and $T_{\text {min }}$ are the temperature and the minimum temperature in the tunnel after closure of tunnel entrance. 
There is a wide range of temperature control measures for concrete placing. In order to be simple and controllable, the pouring temperature $\left(\mathrm{T}_{0}\right)$ is used to reflect the comprehensive influence of all temperature control measures on the initial setting of concrete. Whether adopting water cooling or not and water temperature $\left(\mathrm{T}_{\mathrm{w}}\right)$ are also considered.

In conclusion, nine elements are considered to estimate $\sigma_{\max }$ during concrete construction period, including joint length $(\mathrm{L})$, side wall height $\left(\mathrm{H}_{0}\right)$, lining thickness $(H)$, concrete strength grade $(C)$, temperature $\left(T_{a}\right)$ and minimum temperature $\left(T_{\min }\right)$ in the tunnel, deformation modulus (E) of surrounding rock, concrete pouring temperature $\left(\mathrm{T}_{0}\right)$, whether water cooling or not and water cooling temperature $\mathrm{T}_{\mathrm{w}}$.

\section{Statistical Analysis Based on Finite Element Simulation Calculation Results}

\subsection{Finite Element Simulation Calculation Scheme}

A three-dimensional finite element model is established by typical engineering hydraulic tunnel structure. The above nine elements are defined as follows: $\mathrm{L}=6-12 \mathrm{~m}$, $\mathrm{H}_{0}=8.87-14.87 \mathrm{~m}, \mathrm{H}=0.8 \mathrm{~m}-1.5 \mathrm{~m}$, concrete strength grade is $\mathrm{C}_{90} 30-\mathrm{C}_{90} 60$, temperature in the tunnel during concrete pouring period ranges from $12{ }^{\circ} \mathrm{C}$ to $28{ }^{\circ} \mathrm{C}$ (including different combinations of $\mathrm{T}_{\mathrm{a}}$ and $\mathrm{T}_{\text {min }}$ covering January to December), deformation modulus of surrounding rock is $5-30 \mathrm{GPa}$, concrete placing temperature is $15{ }^{\circ} \mathrm{C}-27^{\circ} \mathrm{C}$, whether water cooling or not is considered, and water cooling temperature is $12^{\circ} \mathrm{C}$ $22{ }^{\circ} \mathrm{C}$. The elastic modulus, adiabatic temperature rise curve, creep parameters and the performance of the surrounding rock of the lining concrete all adopt the actual engineering parameters. For the combination of nine elements in the range of parameters proposed, 174 schemes were simulated by finite element method (FEM), and the maximum tensile stress $\left(\sigma_{\max }\right)$ of side wall lining concrete during construction period was sorted out.

\subsection{Influences of Different Elements On Maximum Tensile Stress $\Sigma_{\max }$ of Lining Concrete During Construction Period}

When analyzing the influence degree and influence law of each factor on $\sigma_{\max }$, taking side wall (14.87m high and 9m slit length) of Class II surrounding rock area (E=30GPa) of flood discharge tunnel as an example, $\mathrm{C}_{90} 40$ lining concrete with $1.0 \mathrm{~m}$ thickness was poured at $18^{\circ} \mathrm{C}$ on July 1 with temperature of $18^{\circ} \mathrm{C}$ and cooled with water at $15^{\circ} \mathrm{C}$ for 15 days as the basis. Specify where elements change. using the measured statistical annual variation curve as temperature in the tunnel, the annual average temperature is $19.29^{\circ} \mathrm{C}$, with a variation of $\pm 6.7^{\circ} \mathrm{C}$.

\subsubsection{Influence of Lining Thickness $H$ on $\sigma_{\max }$}

The relationship between $\sigma_{\max }$ and lining thickness $H$ with water cooling or not is shown in figure 1 . The results show that when $\mathrm{H}$ increases, $\sigma_{\max }$ increases. There is a small non-linear proportional relationship between $\mathrm{H}$ and $\sigma_{\max }$, which can be expressed approximately by linear relationship. While $\mathrm{T}_{\mathrm{a}}$ equals to $25.33^{\circ} \mathrm{C}$ in high temperature season(on July 1), $\sigma_{\max }$ increases by $0.13 \mathrm{MPa} / \mathrm{m}$ with water cooling and $0.41 \mathrm{MPa} / \mathrm{m}$ without water cooling. While $\mathrm{T}_{\mathrm{a}}$ equals to $25.33^{\circ} \mathrm{C}$ in low temperature season(on March 
1), $\sigma_{\max }$ increases by $0.74 \mathrm{MPa} / \mathrm{m}$ with water cooling and $1.06 \mathrm{MPa} / \mathrm{m}$ without water cooling. It should be noted that the growth rate of tensile stress of concrete increases obviously when pouring concrete occurs in low temperature season or no water cooling. The thickness of lining concrete, water cooling or not, water temperature $T_{w}$, and temperature in tunnel $T_{a}$ have a significant cross-impact on the tensile stress $\sigma_{\max }$.

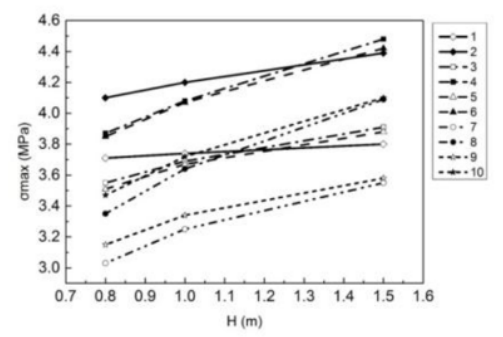

Figure 1. Evolution of $\sigma_{\max }$ with lining thickness $H$.

Note: $1 . \mathrm{T}_{\mathrm{a}}=25.33^{\circ} \mathrm{C}$ in July, with $15^{\circ} \mathrm{C}$ water cooling; $2 . \mathrm{T}_{\mathrm{a}}=25.33^{\circ} \mathrm{C}$ in July without water cooling; 3 . $\mathrm{T}_{\mathrm{a}}=19.32^{\circ} \mathrm{C}$ in November, with $15^{\circ} \mathrm{C}$ water cooling; $4 . \mathrm{T}_{\mathrm{a}}=19.32^{\circ} \mathrm{C}$ in November without water cooling; 5 . $\mathrm{T}_{\mathrm{a}}=19.55^{\circ} \mathrm{C}$ in May, with $15^{\circ} \mathrm{C}$ water cooling; $6 . \mathrm{T}_{\mathrm{a}}=19.55^{\circ} \mathrm{C}$ in May, without water cooling; $7 . \mathrm{T}_{\mathrm{a}}=13.28^{\circ} \mathrm{C}$ in March, with $15^{\circ} \mathrm{C}$ water cooling; $8 . \mathrm{T}_{\mathrm{a}}=13.28^{\circ} \mathrm{C}$ in March, without water cooling; $9 . \mathrm{T}_{\mathrm{a}}=16.21^{\circ} \mathrm{C}$ in April, with $15^{\circ} \mathrm{C}$ water cooling; $10 . \mathrm{T}_{\mathrm{a}}=16.21^{\circ} \mathrm{C}$ in April, without water cooling;

\subsubsection{Effect of Side Wall Height $H_{0}$ on $\sigma_{\max }$}

The relationship between $\sigma_{\max }$ and the height of the side wall $\mathrm{H}_{0}$ is shown in figure 2 . The increase of $\sigma_{\max }$ is $0.046 \mathrm{MPa} / \mathrm{m}$ for $\mathrm{L}=6 \mathrm{~m}$ or $12 \mathrm{~m}$ and $0.035 \mathrm{MPa} / \mathrm{m}$ for $\mathrm{L}=9 \mathrm{~m}$, which indicates that $\mathrm{L}$ and $\mathrm{H}_{0}$ have slight cross-influence. The $\sigma_{\max }$ and $\mathrm{H}_{0}$ can be approximately represented as linear-dependent.

\subsubsection{Effect of Split Length L on $\sigma_{\max }$}

The $\sigma_{\max }$ versus $\mathrm{L}$ is shown in figure 3. $\sigma_{\max }$ increases linearly with L. At $\mathrm{H}_{0}=11.87 \mathrm{~m}$ and $14.87 \mathrm{~m}, \sigma_{\max }$ increases by $0.058 \mathrm{MPa} / \mathrm{m}$, indicating that in the calculation range of $\mathrm{L}$, $\mathrm{H}_{0}$ has little cross-impact on $\sigma_{\max }$.

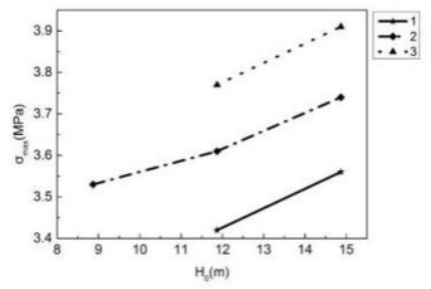

Figure 2. Evolution of $\sigma_{\max }$ with side wall height $\mathrm{H} 0$. 1. $\mathrm{L}=6 \mathrm{~m} ; 2$. $\mathrm{L}=9 \mathrm{~m} ; 3$. $\mathrm{L}=12 \mathrm{~m}$.

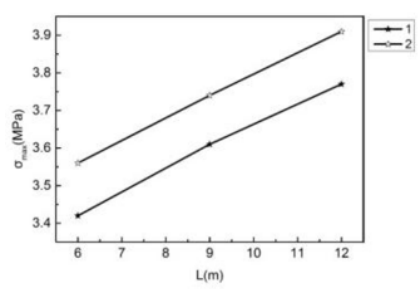

Figure 3. Evolution of $\sigma_{\max }$ with split length $\mathrm{L}$. 1. $\mathrm{H} 0=11.87 \mathrm{~m} ; 2$. $\mathrm{H} 0=14.87 \mathrm{~m}$. 


\subsubsection{Effect of Concrete Strength $C$ on $\sigma_{\max }$}

The relationship between $\sigma_{\max }$ and $\mathrm{C}$ is shown in figure 4 . With the increase of concrete strength, $\sigma_{\max }$ increases nonlinearly and the increase rate decreases when the strength is high. For different thickness $\mathrm{H}, \sigma_{\max }$ increases with $\mathrm{C}$ equally. When $\mathrm{T}_{\mathrm{a}}=25.33^{\circ} \mathrm{C}, \sigma_{\max }$ increases $0.56 \mathrm{MPa} / 10 \mathrm{MPa}$ for $1.0 \mathrm{~m}$ lining concrete and $0.57 \mathrm{MPa} / 10 \mathrm{MPa}$ for $1.5 \mathrm{~m}$ lining concrete. However, in low temperature season, the increase of $\sigma_{\max }$ with $\mathrm{C}$ is smaller than that in summer. When $\mathrm{T}_{\mathrm{a}}=13.28^{\circ} \mathrm{C}, \sigma_{\max }$ increases by $0.49 \mathrm{MPa} / 10 \mathrm{MPa}$ for $1.0 \mathrm{~m}$ lining concrete and $0.50 \mathrm{MPa} / 10 \mathrm{MPa}$ for $1.5 \mathrm{~m}$ lining concrete. Which shows that there is no cross-action between $\mathrm{C}$ and $\mathrm{H}$. $\mathrm{C}$ has little cross-action with $\mathrm{T}_{\mathrm{a}}$.

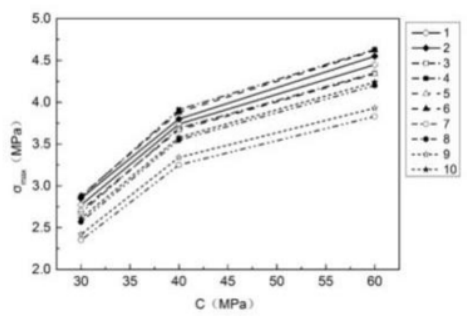

Figure 4. Evolution of $\sigma_{\max }$ with concrete strength $\mathrm{C}$.

Note: $1 . \mathrm{T}_{\mathrm{a}}=25.33^{\circ} \mathrm{C}, \mathrm{H}=1.0 \mathrm{~m} ; 2 . \mathrm{T}_{\mathrm{a}}=25.33^{\circ} \mathrm{C}, \mathrm{H}=1.5 \mathrm{~m} ; 3 . \mathrm{T}_{\mathrm{a}}=19.32^{\circ} \mathrm{C}, \mathrm{H}=1.0 \mathrm{~m} ; 4 . \mathrm{T}_{\mathrm{a}}=19.32^{\circ} \mathrm{C}, \mathrm{H}=1.5 \mathrm{~m}$; 5. $\mathrm{T}_{\mathrm{a}}=19.55^{\circ} \mathrm{C}, \mathrm{H}=1.0 \mathrm{~m} ; 6 . \mathrm{T}_{\mathrm{a}}=19.55^{\circ} \mathrm{C}, \mathrm{H}=1.5 \mathrm{~m} ; 7 . \mathrm{T}_{\mathrm{a}}=13.28^{\circ} \mathrm{C}, \mathrm{H}=1.0 \mathrm{~m} ; 8 . \mathrm{T}_{\mathrm{a}}=13.28^{\circ} \mathrm{C}, \mathrm{H}=1.5 \mathrm{~m} ; 9$. $\mathrm{T}_{\mathrm{a}}=16.21^{\circ} \mathrm{C}, \mathrm{H}=1.0 \mathrm{~m} ; 10 . \mathrm{T}_{\mathrm{a}}=16.21^{\circ} \mathrm{C}, \mathrm{H}=1.5 \mathrm{~m}$.

\subsubsection{Influence of Deformation Modulus E of Surrounding Rock}

The relationship between $\sigma_{\max }$ and $\mathrm{E}$ is shown in figure 5 . When the surrounding rock is hard and complete, the deformation modulus is large, which enhances the restraint of lining concrete, resulting in increase of $\sigma_{\max } . \sigma_{\max }$ and $\mathrm{E}$ present obvious non-linear relationship, and growing tendency decreases when $\mathrm{E}$ is large. For different thicknesses $\mathrm{H}, \sigma_{\max }$ increases equally with $\mathrm{E}$. $\sigma_{\max }$ increase by $0.041 \mathrm{MPa} / \mathrm{GPa}$ for $1.0 \mathrm{~m}$ and $1.5 \mathrm{~m}$ lining concrete poured at $\mathrm{T}_{\mathrm{a}}=25.33^{\circ} \mathrm{C}$. However, in low temperature season, the increase of $\sigma_{\max }$ with $\mathrm{C}$ is slightly smaller than that in summer. When concrete is poured at $\mathrm{T}_{\mathrm{a}}=13.28^{\circ} \mathrm{C}, \sigma_{\max }$ increases by $0.0324 \mathrm{MPa} / \mathrm{GPa}$ for $1.0 \mathrm{~m}$ lining and $0.0368 \mathrm{MPa} / \mathrm{GPa}$ for $1.5 \mathrm{~m}$ lining. It shows that $\mathrm{E}$ and $\mathrm{H}$ have no cross-action on $\sigma_{\max } \mathrm{E}$ has little cross-action with $\mathrm{T}_{\mathrm{a}}$.

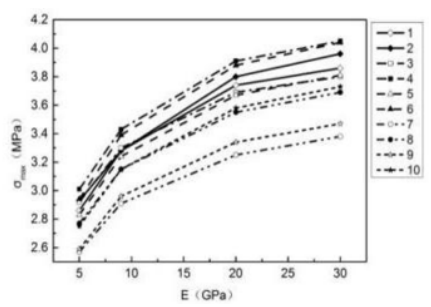

Figure 5. Evolution of $\sigma_{\max }$ with elastic modulus of surrounding rock E.

Note: 1. $\mathrm{T}_{\mathrm{a}}=25.33^{\circ} \mathrm{C}$ in July, $\mathrm{H}=1.0 \mathrm{~m} ; 2 . \mathrm{T}_{\mathrm{a}}=25.33^{\circ} \mathrm{C}$ in July, $\mathrm{H}=1.5 \mathrm{~m} ; 3 . \mathrm{T}_{\mathrm{a}}=19.32^{\circ} \mathrm{C}$ in November, $\mathrm{H}=1.0 \mathrm{~m} ; 4 . \mathrm{T}_{\mathrm{a}}=19.32^{\circ} \mathrm{C}$ in November, $\mathrm{H}=1.5 \mathrm{~m} ; 5 . \mathrm{T}_{\mathrm{a}}=19.55^{\circ} \mathrm{C}$ in May, $\mathrm{H}=1.0 \mathrm{~m} ; 6 . \mathrm{T}_{\mathrm{a}}=19.55^{\circ} \mathrm{C}$ in $\mathrm{May}$, $\mathrm{H}=1.5 \mathrm{~m} ; 7$. $\mathrm{T}_{\mathrm{a}}=13.28^{\circ} \mathrm{C}$ in March, $\mathrm{H}=1.0 \mathrm{~m} ; 8 . \mathrm{T}_{\mathrm{a}}=13.28^{\circ} \mathrm{C}$ in March, $\mathrm{H}=1.5 \mathrm{~m} ; 9 . \mathrm{T}_{\mathrm{a}}=16.21^{\circ} \mathrm{C}$ in April, $\mathrm{H}=1.0 \mathrm{~m} ; 10 . \mathrm{T}_{\mathrm{a}}=16.21^{\circ} \mathrm{Cin}$ April, $\mathrm{H}=1.5 \mathrm{~m}$. 


\subsubsection{Influence of Pouring Temperature $T_{0}$}

The relationship between $\sigma_{\max }$ and pouring temperature $T_{0}$ is shown in figure 6 . With the increase of $T_{0}$, the maximum internal temperature increases, $\sigma_{\max }$ increases linearly, when $\mathrm{T}_{0}$ increases by $1.0 \%, \sigma_{\max }$ increases by $0.14-0.16 \mathrm{MPa} /{ }^{\circ} \mathrm{C}$. The thickness of lining and $\mathrm{T}_{0}$ have little cross-influence on $\sigma_{\max }$, the growth rate of $\sigma_{\max }$ is slightly larger when the thickness is large.

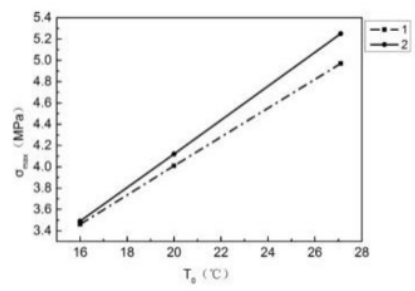

Figure 6. Evolution of $\sigma \max$ with curing temperature. T0. 1. $\mathrm{H}=1.0 \mathrm{~m} ; 2 . \mathrm{H}=1.5 \mathrm{~m}$.

\subsubsection{Influence of Cooling Water Temperature of Flow Water $T_{w}$}

The relationship between $\sigma_{\max }$ and water cooling water temperature $\mathrm{T}_{\mathrm{w}}$ is shown in figure 7 . As the $\mathrm{T}_{\mathrm{w}}$ rises, $\sigma_{\max }$ increases by $0.018-0.03 \mathrm{MPa} /{ }^{\circ} \mathrm{C}$, which is basically linear. Different strength, thickness and pouring temperature have little cross-influence on $\sigma_{\max }$.

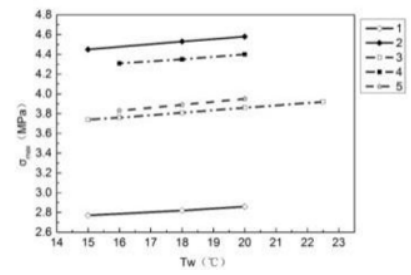

Figure 7. Evolution of $\sigma_{\max }$ with water temperature $\mathrm{T}_{\mathrm{w}}$. 1. $\mathrm{C}=30 \mathrm{MPa}, \mathrm{H}=1.0 \mathrm{~m} ; 2 . \mathrm{C}=60 \mathrm{MPa}, \mathrm{H}=1.0 \mathrm{~m}$; 3. $\mathrm{T}_{0}=18^{\circ} \mathrm{C}, \mathrm{H}=1.0 \mathrm{~m} ; 4 . \mathrm{T}_{0}=22^{\circ} \mathrm{C}, \mathrm{H}=1.0 \mathrm{~m} ; 5 . \mathrm{T}_{0}=18^{\circ} \mathrm{C}, \mathrm{H}=1.5 \mathrm{~m}$.

\subsubsection{Effect of Air Temperature In Tunnel}

There are two situations to study the influence of temperature in the tunnel on $\sigma_{\max }$. One is to cast concrete on July 1 with $\mathrm{T}_{\mathrm{a}}=25.33^{\circ} \mathrm{C}$. The lowest temperature $\mathrm{T}_{\min }$ in winter change with the annual variation curve of temperature in the tunnel. The evolution of $\sigma_{\max }$ with $T_{\min }$ is shown in figure 8. The other situation is the annual variation curve of air temperature in the tunnel remains unchanged. Concrete is poured in different months ( $\mathrm{T}_{\mathrm{a}}$ is also different). The relationship between $\sigma_{\max }$ and air temperature in the tunnel during concrete pouring is shown in figure 9 and the relationship between $\sigma_{\max }$ and pouring date is shown in figure 10 . 


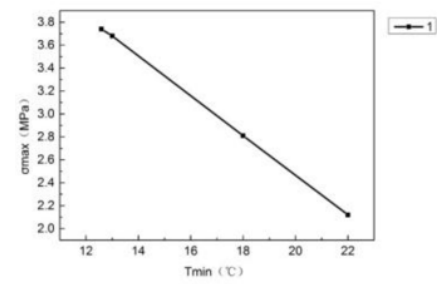

Figure 8. Evolution of $\sigma_{\max }$ with minimum temperature $T_{\min }$.

Figure 8 shows that $\sigma_{\max }$ is inversely proportional to $\mathrm{T}_{\min }$, and $\sigma_{\max }$ decreases by $0.17 \mathrm{MPa}$ when $\mathrm{T}_{\min }$ increases by $1.0 \mathrm{C}$. Since there is no change in temperature in the tunnel during pouring, $\sigma_{\max }$ is proportional to the difference between temperature $T_{a}$ in the tunnel during pouring and minimum temperature $T_{\min }$ in winter $\left(T_{a}-T_{\min }\right)$. The greater the temperature difference $\left(\mathrm{T}_{\mathrm{a}}-\mathrm{T}_{\min }\right)$, the greater the $\sigma_{\max }$.

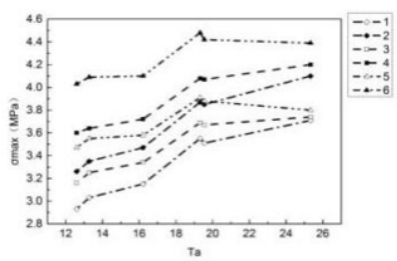

Figure 9. Evolution of $\sigma_{\max }$ with $\mathrm{T}_{\mathrm{a}}$.

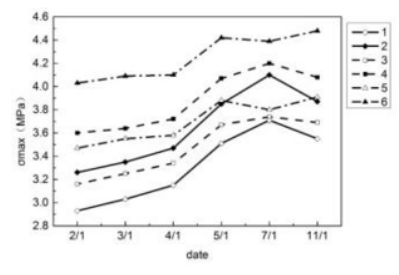

Figure 10. Evolution of $\sigma_{\max }$ with curing data.

1. $\mathrm{H}=0.8 \mathrm{~m}$ with water cooling; 2 . $\mathrm{H}=0.8 \mathrm{~m}$ without water cooling; 3 . $\mathrm{H}=1.0 \mathrm{~m}$ with water cooling; 4 . $\mathrm{H}=1.0 \mathrm{~m}$ without water cooling; 5 . $\mathrm{H}=1.5 \mathrm{~m}$ with water cooling; $6 . \mathrm{H}=1.5 \mathrm{~m}$ without water cooling

From figure 9 and figure 10 , it can be seen that $T_{a}$ (i.e. $T_{a}-T_{\min }$ ) varies due to concrete placed in different months, especially the curing age and elastic modulus of concrete while reaching $\mathrm{T}_{\min }$ vary in winter. Also, the temperature stress produced by the same temperature difference is significantly different. Therefore, $\sigma_{\max }$ and $T_{a}$ show obvious non-linear relationship. Furthermore, $\sigma_{\max }$ can vary even if $\mathrm{T}_{\mathrm{a}}$ is almost the same when concrete is placed in May and November. Of course, due to the small difference, the relation between $\sigma_{\max }$ and Ta can be simply expressed as non-linear if the error caused by this influence is ignored. There is little difference in the influence of $\mathrm{T}_{\mathrm{a}}$ on $\sigma_{\max }$ under different thickness, i.e. there is little cross-influence between them.

\subsubsection{Statistical Analysis of Maximum Tensile Stress of Lining Concrete During Construction Period}

Based on the above analysis, the relationship between maximum temperature tensile stress $\sigma_{\max }$ and various factors during lining concrete construction period is recognized as follows:

(1) The major influencing factors for $\sigma_{\max }$ are $\mathrm{H}, \mathrm{H}_{0}, \mathrm{~L}, \mathrm{C}, \mathrm{E}, \mathrm{T}_{\mathrm{a}}$ in the tunnel during pouring period and $\mathrm{T}_{\min }$ in winter (or $\mathrm{T}_{\mathrm{a}}-\mathrm{T}_{\min }$ ), $\mathrm{T}_{0}, \mathrm{~T}_{\mathrm{w}}$, and whether cooling with water or not.

(2) The relationship between $\sigma_{\max }$ and C、E、 $T_{a}$ is obviously non-linear, while the rest can be expressed approximately by linear relation. 
(3) Among the nine influencing factors, $\mathrm{H}$ has cross-influence on $\sigma_{\max }$ with $\mathrm{C}, \mathrm{E}$, $\mathrm{T}_{\mathrm{a}}, \mathrm{T}_{0}, \mathrm{~T}_{\mathrm{w}} . \mathrm{C}, \mathrm{T}_{0}$ and $\mathrm{E}$ have little cross-influence with $\mathrm{T}_{\mathrm{a}}$, and the rest factors have no cross-influence.

(4) $T_{a}$ indicates the influence of cast season and air temperature in the tunnel during pouring, and additional variables $\left(\mathrm{T}_{\mathrm{a}}-\mathrm{T}_{\min }\right)$ are required.

Based on this analysis and through further optimum statistical analysis, the estimation formula of maximum tensile stress $\sigma_{\max }$ in concrete lining of tunnel side wall is obtained.

$$
\begin{aligned}
& \sigma_{\max }=0.386 \mathrm{H}+0.011 \mathrm{H}_{0}+0.058 \mathrm{~L}+0.041 \mathrm{C}+0.031 \mathrm{E}-0.0002 \mathrm{E}^{2}+0.1448 \mathrm{~T}_{0}-0.002 \mathrm{~T}_{\mathrm{g}}- \\
& 0.14 \mathrm{~T}_{\mathrm{a}}+0.197\left(\mathrm{~T}_{\mathrm{a}}-\mathrm{T}_{\min }\right)+0.015 \mathrm{H} \times \mathrm{T}_{0}-0.022 \mathrm{H} \times \mathrm{T}_{\mathrm{g}}+0.0071 \mathrm{E} \times \mathrm{H}+0.0071 \mathrm{H} \times \mathrm{C}- \\
& 0.042 \mathrm{H} \times\left(\mathrm{T}_{\mathrm{a}}-\mathrm{T}_{\min }\right)-0.882
\end{aligned}
$$

In the equation, $\mathrm{T}_{\mathrm{g}}$ is the equivalent variable for water cooling and its water temperature, i.e. $\mathrm{T}_{\mathrm{g}}=35-\mathrm{T}_{\mathrm{w}} . \mathrm{T}_{\mathrm{w}}$ equals to $35^{\circ} \mathrm{C}$ for non-water cooling. The remaining symbols have the same meaning as before.

It must be pointed out that when $28 \mathrm{~d}$ design strength grade is used for lining concrete, it needs to be converted to $90 \mathrm{~d}$ design strength grade.If enclosed openings are used for insulation, increased values should be used for $\mathrm{T}_{\mathrm{a}}$ and $\mathrm{T}_{\min }$. The calculation formula is suitable for medium-hot cement concrete with lining thickness of $0.8 \mathrm{~m}-1.5 \mathrm{~m}$, single row spacing of water cooling pipes of $1.5 \mathrm{~m}$ and cooling water temperature of water passing below $35^{\circ} \mathrm{C}$.

\section{Real-Time Control of Temperature Control and Crack Prevention in Concrete Construction of Side Wall Lining of Flood Discharge Tunnel}

City door-shaped tunnel section is used in the unconfined section of a flood discharge tunnel of a hydropower station. The lining thickness in Class II and III surrounding rock areas of the Longluowei Section is $1.0 \mathrm{~m}$, the slit length is $9.0 \mathrm{~m}$ (figure 11), and the strength of medium-hot cement concrete is $\mathrm{C}_{90} 60$ (anti-scour and anti-wear).The tensile strength of concrete is $2.86 \mathrm{MPa}$ for $7 \mathrm{~d}, 3.82 \mathrm{MPa}$ for $28 \mathrm{~d}$ and $4.15 \mathrm{MPa}$ for 90d.The pouring temperature required for design is $18^{\circ} \mathrm{C}$ (concrete is provided at outlet of mixing building with $14^{\circ} \mathrm{C}$ ), cooling with water temperature of $12^{\circ} \mathrm{C}-22^{\circ} \mathrm{C}$ and maximum allowed temperature is $39^{\circ} \mathrm{C}$ in inner concrete.

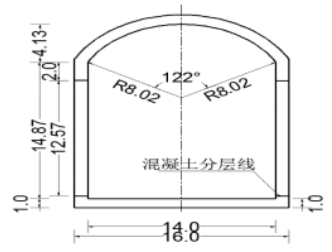

Figure 11. Lining section of longluowei section (unit: m).

In order to control temperature and prevent crack more effectively, real-time temperature control and crack prevention control are carried out in the lining concrete 
placing of the tail section of the flood discharge tunnel.The specific method and process are as follows:

(1) Measure the temperature $T_{a}$ in the tunnel and the temperature $T_{w}$ of cooling water before concrete placing. The results are shown in table 1 .

(2) Forecast $\sigma_{\max }$. The calculation parameters of $\mathrm{H}, \mathrm{H}_{0}$ (cast by stages of side wall and crown arch), $\mathrm{L}, \mathrm{C}, \mathrm{T}_{0}, \mathrm{~T}_{\min }$ (average annual measured value) are $1.0 \mathrm{~m}, 12.57 \mathrm{~m}, 9 \mathrm{~m}$, $60 \mathrm{MPa}, 18^{\circ} \mathrm{C}, 12.59^{\circ} \mathrm{C}$ respectively. $\mathrm{E}, \mathrm{T}_{\mathrm{a}}$ and $\mathrm{T}_{\mathrm{w}}$ (measured value) are shown in Table 1. Acording to Eq.(1), the calculated values of $\sigma_{\max }$ are also listed in table 1 .

(3) Prediction of safety factor K for crack resistance based on Eq.(2).

$$
\mathrm{K}=[\sigma] / \sigma_{\max }
$$

$[\sigma]$ is tensile strength consistent with the same age as $\sigma_{\max }$. According to the statistics of 174 schemes mentioned above, $\sigma_{\max }$ occurred around 1st February the following year. The age of $[\sigma]$ is dating from concrete placement to February 1 , which is calculated by Eq. (3) .

$$
[\sigma]=3.82 \times[1+0.1813 \times \ln (\tau / 28)]
$$

Eq. (3) is obtained by statistical analysis of tensile strength of $\mathrm{C}_{90} 60$ (anti-scour and abrasion) concrete at ages of $7 \mathrm{~d}, 28 \mathrm{~d}$ and $90 \mathrm{~d}$ using the recommended exponential function. $\tau$ is the age for calculation, and the age from concrete placement to January $1^{\text {st }}$ is taken here. The predicted $\mathrm{K}$ value of lining concrete is shown in table 1 .

(4) Determine the scheme of temperature control measures. $\mathrm{K}$ is controlled to be greater than 1.2-1.3. If the requirement can not be met, the scheme of temperature control measures is adjusted in real time to reduce the pouring temperature or cooling water temperature of flow water properly. Trough real-time control, the safety factor $\mathrm{K}$ for crack resistance of concrete in each silo is greater than 1.3 (seen in table 1), and the minimum value is 1.38 .

Table 1. Calculation and effect of real-time temperature control and crack prevention of lining concrete at

\begin{tabular}{|c|c|c|c|c|c|c|c|c|c|c|c|c|}
\hline \multirow{2}{*}{ No. } & \multirow{2}{*}{$\begin{array}{l}\text { The date for } \\
\text { casting }(\mathrm{m} / \mathrm{d})\end{array}$} & \multirow{2}{*}{$\begin{array}{c}\mathrm{E} \text { for } \\
\text { surrounding } \\
\text { rock } \\
/ \mathrm{GPa}\end{array}$} & \multicolumn{3}{|c|}{ Predicted value } & \multicolumn{6}{|c|}{ Measured value } & \multirow{2}{*}{ Crack } \\
\hline & & & $\mathrm{T}_{0} /{ }^{\circ} \mathrm{C}$ & $\sigma_{\max / \mathrm{MPa}}$ & $\mathrm{K}$ & $\mathrm{T}_{0} /{ }^{\circ} \mathrm{C}$ & $\begin{array}{r}\mathrm{T}_{\mathrm{a}} \\
{ }^{\circ} \mathrm{C} \\
\end{array}$ & $\begin{array}{r}\mathrm{T}_{\mathrm{w}} \\
/{ }^{\circ} \mathrm{C} \\
\end{array}$ & $\begin{array}{l}\mathrm{T}_{\max } \\
/{ }^{\circ} \mathrm{C} \\
\end{array}$ & $\sigma_{\max / \mathrm{MPa}}$ & $\begin{array}{c}\text { Calculated } \\
\mathrm{K}\end{array}$ & \\
\hline 105 & $3 / 26$ & 9 & 18 & 3.02 & 1.81 & 16.5 & 28.6 & 16.2 & 32.5 & 2.81 & 1.95 & no \\
\hline 104 & $4 / 15$ & 9 & 18 & 3.16 & 1.72 & 17.2 & 19 & 21.2 & 35.8 & 3.04 & 1.79 & no \\
\hline 103 & $4 / 25$ & 9 & 18 & 3.19 & 1.7 & 18.7 & 23.6 & 22.3 & 37.5 & 3.29 & 1.64 & no \\
\hline 102 & $5 / 8$ & 9 & 18 & 3.23 & 1.66 & 23 & 28.6 & 23.7 & 39.2 & 3.96 & 1.36 & no \\
\hline 101 & $5 / 16$ & 20 & 18 & 3.6 & 1.49 & 16.1 & 26.3 & 24 & 36.7 & 3.33 & 1.61 & no \\
\hline 100 & $5 / 25$ & 20 & 18 & 3.62 & 1.47 & 17 & 24.7 & 24.4 & 38.9 & 3.47 & 1.54 & no \\
\hline 99 & $6 / 5$ & 20 & 18 & 3.63 & 1.46 & 16.6 & 27.1 & 24.5 & 37.8 & 3.42 & 1.55 & no \\
\hline 98 & $6 / 14$ & 20 & 18 & 3.67 & 1.44 & 21.8 & 27.8 & 25.9 & 40.9 & 4.22 & 1.25 & no \\
\hline 97 & $7 / 16$ & 20 & 18 & 3.52 & 1.47 & 20.1 & 27.3 & 19.1 & 45.9 & 3.82 & 1.36 & yes \\
\hline 95 & $8 / 5$ & 20 & 18 & 3.51 & 1.46 & 21.8 & 26.3 & 18.7 & 36.1 & 4.06 & 1.26 & no \\
\hline 94 & $8 / 12$ & 20 & 18 & 3.51 & 1.45 & 21.5 & 27.9 & 18.8 & 39.4 & 4.02 & 1.27 & no \\
\hline 90 & $8 / 19$ & 20 & 18 & 3.6 & 1.4 & 22.5 & 28.6 & 22.7 & 37.6 & 4.25 & 1.19 & no \\
\hline 92 & $8 / 25$ & 20 & 18 & 3.59 & 1.4 & 21.4 & 28.4 & 22.5 & 35.5 & 4.09 & 1.23 & no \\
\hline 89 & $9 / 20$ & 20 & 18 & 3.55 & 1.38 & 17 & 26.5 & 21.1 & 34.2 & 3.4 & 1.44 & no \\
\hline
\end{tabular}
the tail end of $4 \#$ spillway tunnel 
(5) Real-time temperature control and detection during concrete placement. The parameters related to calculation, such as pouring temperature $T_{0}$, temperature $T_{a}$ in tunnel, cooling water temperature $T_{w}$ and maximum temperature $T_{\max }$ in concrete are shown in table 1. According to the results of construction inspection, temperature stress $\sigma_{\max }$ and crack resistance safety factor $\mathrm{K}$ are calculated again and the results are also listed in table 1.

(6) Effect of real-time control. Both $T_{0}$ and $T_{w}$ in 8 silos measured exceed the design requirement. Under this circumstance, $\mathrm{T}_{\max }$ is well controlled, with only 4 silos over $39^{\circ} \mathrm{C}$. Temperature cracks of concrete are effectively controlled. Cracks occur in only 1 silo due to $\mathrm{T}_{\max }$ reaching $45.9^{\circ} \mathrm{C}$ (harmless requirement for post-treatment), which is significantly less than similar projects $[1,5,19]$. According to the measured $\mathrm{T}_{0}$, $\mathrm{T}_{\mathrm{a}}, \mathrm{T}_{\mathrm{w}}$ and relevant parameters, $\sigma_{\max }$ is calculated as $2.81-4.25 \mathrm{MPa}$ and $\mathrm{K}$ equals to 1.19-1.95, which indicates that the risk of temperature cracks in concrete is not high, which is consistent with the actual result that only one silo has cracks. The calculation Eqs. (1) and (2) can well reflect the temperature stress and crack resistance safety characteristics of lining concrete side wall.

\section{Conclusion}

Through the comprehensive analysis and finite element simulation of the factors affecting the temperature stress during the construction period of tunnel lining concrete, nine factors that affect $\sigma_{\max }$ during construction period of lining concrete are determined, i.e. three-dimensional structure size $\mathrm{H}, \mathrm{H}_{0}$, L, concrete strength grade $\mathrm{C}$, deformation modulus $\mathrm{E}$, air temperature $\mathrm{T}_{\mathrm{a}}$ (including the lowest temperature $\mathrm{T}_{\min }$ in winter), pouring temperature $T_{0}$, whether water cooling or not, and water temperature $\mathrm{T}_{\mathrm{W}}$ in the tunnel. The results show that there is a obvious nonlinear relationship between $\sigma_{\max }$ and $\mathrm{C}, \mathrm{E}, \mathrm{T}_{\mathrm{a}}$, and the rest can be expressed approximately by linear relationship; There is a cross effect between $\mathrm{H}$ and $\mathrm{C}, \mathrm{E}, \mathrm{T}_{\mathrm{a}}, \mathrm{T}_{0}$ on $\sigma_{\max }$, there is a small cross effect between $\mathrm{C}$ and $\mathrm{T}_{\mathrm{a}}, \mathrm{T}_{0}$ and $\mathrm{E}$ and $\mathrm{T}_{\mathrm{a}}$, the rest have no cross effect.

Based on the results of finite element simulation, the estimation Eq. (1) of the maximum tensile stress of hot cement concrete in tunnel lining side wall is proposed, and the influence law and influence degree of nine factors on the force are revealed. Through the real-time control of temperature control and crack prevention for lining concrete of spillway tunnel longluowei structure section, the scientificity and calculation accuracy of Eq. (1) and the effectiveness of real-time control method are verified. The real-time control of temperature control and crack prevention for lining concrete pouring of spillway tunnel can effectively achieve the goal of temperature control and crack prevention, and can be extended to practical engineering application.

\section{References}

[1] Fan QX, Duan YH, et al. Innovation and practice of temperature control and crack prevention of hydraulic tunnel lining concrete. In: 1st, editors. Study on crack prevention of lining concrete of spillway tunnel of Xiluodu Hydropower Station. Beijing: China Water Conservancy and Hydropower Press; 2015. p. 4-7.

[2] Fan QX and Li RC. Experimental study on temperature control of lining concrete and analysis of crack causes. China Three Gorges Construction. 2001 May; (5): 11-13. 
[3] Duan YH, Fang CY, Fan QX, et al. Temperature field test study on lining concrete of water conveyance tunnel of Three Gorges permanent ship lock. Journal of Rock Mechanics and Engineering. 2006 Jan; 25 (1): 128-135.

[4] Duan YH, Peng Y, Luo G, et al. Mechanism and development of temperature cracks in lining concrete of portal section. Journal of Wuhan University (Engineering Edition). 2018 Oct; 51(10): 847-852.

[5] Liao B. The cause and prevention of cracking in high strength concrete of Xiaolangdi Project's outlet works. Journal of Hydraulic Engineering. $2001 \mathrm{Jul}$; (7): 47-50+56.

[6] Zhang J, Duan YH, Wang JM. Temperature control research on spiral case concrete of Xiluodu underground power plant during construction. Applied Mechanics and Materials. 2013 Jul; 328: 933941.

[7] Zhang J, Duan YH. Research on Xiluodu underground engineering flood discharging tunnel longluowei section lining concrete with cooling pipes. Journal of Applied Sciences. 2013 Jan; 13(18): 3810-3814.

[8] Fang CY, Duan YH. Analysis of the results of temperature and stress monitoring during the construction period of the water conveyance tunnel lining of the Three Gorges permanent ship lock. Journal of Wuhan University (Engineering Edition). 2003 Oct; 36 (5):30-34.

[9] Guo XN, Duan YH, Chen TF. Temperature observation and stress analysis during the construction of lining concrete of water conveyance tunnel. China Rural Water Conservancy and Hydropower. 2004 Jul; (7): 53-55.

[10] Wang Y, DuanYH. Study on temperature control of lining concrete of water conveyance tunnel of permanent ship lock of Three Gorges Project. Journal of Wuhan University (Engineering Edition). 2001 Apr; 34(3): 32-36.

[11] Wang CF, Liu DF, DuanYH. Observation and analysis of concrete temperature and stress in water conveyance system of permanent ship lock. Journal of Three Gorges University (Natural Science Edition). 2005 Feb; (1): 11-13.

[12] Wang Y, DuanYH, Zhou HL. Study on temperature stress of concrete by equivalent creep degree. China Rural Water Conservancy and Hydropower. 2001 Dec; (1): 81-83.

[13] Chen TF, DuanYH, Wang Y, et al. Theoretical analysis method for temperature stress of tunnel lining concrete during construction. Shandong water conservancy. 2001 May; (5): 33-34.

[14] Fang CY, DuanYH. Calculation of temperature stress during tunnel lining construction by using the embedded plate theory. China Rural Water Conservancy and hydropower. 2003 Nov; (11): 59-61.

[15] Liu Q, Yang J, Liao GY. Temperature control design of high strength lining concrete for large spillway tunnel of Xiluodu Hydropower Station. Design of hydropower station. 2011 Sep; 27 (3): 67-70.

[16] Yan SQ, Cao XH, Kang YB. Analysis of temperature control standard for lining concrete of high-grade tunnel of Xiaolangdi Project. Journal of North China Institute of water resources and hydropower. 2003 Jun; 24(2): 20-23.

[17] Kumar P, Singh B. Design of reinforced concrete lining in pressure tunnels, considering thermal effects and jointed rockmass. Tunnelling and Underground Space Technology. 1990 Jan; 5(1-2): 91-101.

[18] Takayama H, Nonomura M, Masuda Y, et al. Study on cracks control of tunnel lining concrete at an early age. Proceedings of the 33rd ITA-AITES World Tunnel Congress; 2007 May 5-10; Prague, Czech Republic; p.1409-1415.

[19] Zhao L, Feng Y, DuanYH, et al. Occurrence and development process of concrete cracks in the lining of Sanbanxi spillway tunnel. Hydroelectric power. $2011 \mathrm{Sep} ; 37(9)$ : 35-38. 